\title{
Revisiting the Penalty of Illicit Enrichment Crime in Ethiopia: Lessons from Hong Kong and Rwanda's Legal Experiences
}

\author{
LL.B, LL.M, Diriba Adugna Tulu \\ Attorney General Office Of Oromia Regional State, Finfinne, Ethiopia
}

\begin{abstract}
The crime of illicit enrichment has been widely accepted as a useful mechanism for curbing corruption and established in many international and regional anti-corruption instruments such as United Nations Convention Against Corruption (UNCAC), African Union Convention on Preventing and Combating Corruption (AUCPCC), and Inter-American Convention Against Corruption (IACAC). These conventions encourage states parties to criminalize it as part of efforts to fight against corruption crimes. Accordingly, the crime of illicit enrichment is prescribed under Article 21 of the Corruption Crimes Proclamation No. 881/2015 of the Ethiopia. This provision is designed to combat and prevent corrupt practice in public and private sectors. The main objective of this paper is to comparatively analyze the rationality and appropriateness of the penalty provided for illicit enrichment crime in Ethiopian Corruption Crimes Proclamation in comparison with Hong Kong and Rwanda's legal regimes in order to draw some best lessons and way forwards for the identified problems. The paper found that the Ethiopia Corruption Crimes Proclamation fails to set a minimum limit of penalty and entails severe punishment in terms of imprisonment and fine that can convey a meaningful message to potential offenders. Thus, the penalty provided for crime of illicit enrichment is designed in a manner in which the person who commits such crime has the chance to be less punished. In effect, this provision is not only inconsistent with the purpose of criminal law and major sentencing principles, but it also degenerating public confidence in the justice system. Therefore, Ethiopia needs to take a lesson from the experiences of the Hong Kong and Rwanda in incorporating severe and setting minimum limit of penalty for crime of illicit enrichment that can convey a meaningful message to potential offenders. And also, the lawmaker's should amend and redesign the provision with the appropriate penalty.
\end{abstract}

Keywords: Corruption, Corruption Crimes Proclamation, Illicit Enrichment crime, Penalty, Punishment DOI: $10.7176 / \mathrm{JLPG} / 103-01$

Publication date: November $30^{\text {th }} 2020$

\section{Introduction}

Corruption crime constitutes one of the most serious problems that the world is facing today (Okechukwu, Igwe \& Ezenwafor, 2017, Pp.225-243). There is no single country in the world can claim that it is free from any corruption practices (Birney, M, 2013, p.1). In this regard, Ethiopia is not exceptional to this issue (Transparency International's Corruption Perceptions Index from 2017-2019).

There are different types of corruption crimes. Illicit enrichment is one kind of corruption crime. It is one of the proceeds of corruption crimes committed during the period of service by public officials (Ndiva Kofele-Kale, 2012, p.3; Mohannad Ahmad et al, 2016, Pp. 100-105). However, due to its secret nature, making the detection and prosecution of illicit enrichment through traditional mechanism is very difficult. Accordingly, it is considered as one of the most complicated corruption crimes due to lack of proof, where money is the only tangible evidence (Ndiva Kofele-Kale, 2012, p.3).

In order to tackle illicit enrichment crime, various international and regional anti-corruption instruments and strategies are adopted and came in to force with the intention of preventing and combating corruption in a coordinated manner (IACAC, Mar. 29, 1996, 35 I.L.M. 724; See also AUCPCC, July11, 2003, 43 I.L.M. 5; See also UNCAC, 2003).

Ethiopia is a party to most international and regional anti-corruption instruments. It has signed and ratified UNCAC (Proclamation No. 544/2007) and the AUCPCC (Proclamation No. 545/2007). To ensure its commitments under those conventions, the government of Ethiopia has criminalized illicit enrichment crime under Article 21 of Corruption Crimes Procl.No.881/2015 (Article 21 of the Corruption Crimes Proclamation, No. 881/2015). For this crime, the law provides penalty based on the gravity of the crime, degree of individual guilt, and other circumstances of its commission.

This paper intended to examine the rationality and appropriateness of the penalty provided for illicit enrichment crime under Article 21 of the Corruption Crimes Proclamation No. 881/2015 in comparison with other jurisdictions.

\section{Research Method}

As the topic itself suggests, doctrinal approach and comparative perspectives were employed to achieve the objective of the paper and was operational zed via desktop research. Thus, doctrinal methodology was used to in- 
depth analysis of laws in relation to the subject matter of the research, where as comparative study was used to obtain the best lessons of legal framework dealing illicit enrichment crime from foreign jurisdictions. For comparative analysis, the normative framework of Hong Kong and Rwanda were considered. The reason for choosing these countries for a comparative analysis is that both countries have already criminalized illicit enrichment under their respective anti-corruption legal regimes (Prevention of Bribery Ordinance (POBO)(1971), Cap 201 Laws of Hong Kong, Section 10; Law № 54/2018 OF 13/08/2018 on Fighting Against Corruption, Article 9). These countries have very low corruption levels and rank the cleanest countries in the world. Thus, as per Transparency International's Corruption Perceptions Index of the; 2017, 2018 and 2019, Hong Kong scored 77, 76 and 76 against a clean score of 100 in the years under consideration respectively and most taken as exemplary in fighting Corruption Crime; and 2017, 2018 and 2019, Rwanda scored 55, 56 and 53 against a clean score of 100 in the years under consideration respectively and most taken as exemplary in reducing corruption crimes.

\section{Literature Review: The Conceptual and Normative Framework of Illicit Enrichment Crime 3.1. Historical Origin and Development of Illicit Enrichment Crime}

Illicit enrichment crime is relatively a new form of crime compared with other forms of corruption crimes such as bribery, fraud and embezzlement (Jeffrey R. Boles, 2014, p. 849). But, it is not entirely true that illicit enrichment is a new crime. It is new only in the sense that it did not exist in the tradition of the common law but it has long been a recognized crime in many states that follow the Latin American legal Tradition (Ndiva KofeleKale, 2012, p.16). The origins of illicit enrichment as a crime date back to 1936, when Argentinian congrssman Rodolfo Corominas Segura encountered a fellow public official ostentatiously displaying new found wealth while traveling to Buenos Aires by train(Lindy Muzila et al, 2012, p.8). Corominas Segura noticed that the official could not have acquired such wealth from a legitimate source and immediately announced law to punish public officials who accrued wealth without justifying for its source (Max Weylandt, 2017, Pp.2-3).Though, this particular legislation did not pass straight away, Argentina become the first jurisdiction to criminalize illicit enrichment in 1964 (Max Weylandt, 2017, Pp.2-3; Lindy Muzila et al, 2012, p.8).

During the 1970s and 1980s, lawmakers from various countries introduced illicit enrichment laws, and by 1990, at least 10(ten) countries had enacted such laws (Lindy Muzila et al, 2012, p.8). The rates of enactment of legislation then speed up. The UN reports shows that: "by 1990, illicit enrichment had been criminalized in at least 10 (ten) countries, by 2000 in more than 20(twenty) countries, and by 2010 in more than 40 (forty) countries" (Max Weylandt, 2017, Pp.2-3; Lindy Muzila et al, 2012, p.8).

Afterwards, several regional and international anti-corruption conventions were established and setup specific requirements to respond illicit enrichment of public officials. The first international anti-corruption is the IACAC, to which 33 countries in Central and Latin American are party, and which makes it obligatory for members to enact illicit enrichment legislation (Max Weylandt, 2017, p.3).The wording of Article IX of this convention is borrowed from the Argentine Criminal Code which has included a crime of illicit enrichment for decades (Ndiva Kofele-Kale, 2012, p.16). Then after, the AUCPCC also followed in 2003 and finally the UNCAC, also approved in 2003 and entered into force in 2005 (Lindy Muzila et al, 2012, p.9). The UNCAC has been a very powerful document concerning to illicit enrichment regulation, as it is a widely adopted instrument (Max Weylandt, 2017, p.3). As of April 2019, it had 140 signatories and 186 parties (UNODOC, "Signatories to the UNCAC," 2 April, 2019, Retrieved from https://www.unodc.org/unodc/en/corruption/ratificationstatus.html).

Nowadays, illicit enrichment crime provisions can be found in most regions of the globe, with particular exceptions of North America and most of Western Europe (Lindy Muzila et al, 2012, p.9).

\subsection{International and Regional Normative Framework of Illicit Enrichment Crime}

Definitions of illicit enrichment crime establish and draw the essential ingredient elements of the crime, which are fundamental components that should be fulfilled in order for a perpetrator to be found guilty (Mouhamed Bachir, 2017, p.2; Lindy Muzila et al, 2012, p.11 ). Illicit enrichment crime is one of the proceeds of corruption crimes committed during the period of service, such as bribery, embezzlement and investment of public office by public officials ((Mouhamed Bachir, 2017, p.2; Ndiva Kofele-Kale, 2012, p.3). It is presumed that all the assets possessed by the public official, and not covered by his legitimate income, are acquired by the unidentified crimes of corruption. This exactly reflects the dangerous component of such crime. Due to its secret nature, making the detection and prosecution of illicit enrichment crime is very difficult. To tackle the evidential problems linked to proving and to curb unlawful accumulation of wealth by public officials, the crime of illicit enrichment has been developed in various international ant-corruption legal instruments (UNCAC, Article 20; IACAC, Article 9; AUCPCC, Article 8).

Accordingly, the crime of illicit enrichment is defined variously in the different instruments that establish it. International anti-corruption instruments attempt to make consistent of the basic elements of the crime in 
different countries, but, as we will see that there are differences still exist between the key relevant conventions (Lindy Muzila et al, 2012, p.9). In spite of these differences, there are greater similarities than differences among the domestic approaches adopted (Lindy Muzila et al, 2012, p.11). As a result, the trend has been toward developing some common essential elements of illicit enrichment crime (Lindy Muzila et al, 2012, p.11). For instance, the UNCAC defines this crime under Article 20 as follows: "A crime that shows a significant increase in the assets of a public official, which he or she cannot reasonably explain in relation to his or her lawful income and it is committed intentionally"(UNCAC , Article 20).

It is important to stress that UNCAC is not the only international anti-corruption instrument which defines illicit enrichment crime, but also Article 4(1)(g) of the AUCPCC makes illicit enrichment an "act of corruption" and "crime", and the definition of illicit enrichment as clearly stipulate in Article 1(1) is(Karen Zadoyan, 2014):

Illicit enrichment means the significant increase in the assets of a public official or any other persons which he or she cannot reasonable explain in relation to his or her income (AUPCC, Article1(1)).

Furthermore, the IACAC also defined it as follows:

Subject to its Constitution and the fundamental principles of its legal system, each State Party that has not yet done so shall take necessary measures to establish under its laws as an offence a significant increase in the assets of a government official that he cannot reasonably explain in relation to his lawful earnings during the performance of his functions (IACAC, Article 9).

Although the crime of "illicit enrichment" is defined and established in the above three most important multilateral anti-corruption conventions, only the IACAC uses mandatory language in proscribing it. The other two conventions, the UNCAC and AUCPCC, use non-mandatory language, such as the language used in Article 8 (1) of the AUCPCC: "Subject to the provisions of their domestic law, state parties undertake to adopt necessary measures to establish under their laws an offence of illicit enrichment"'( AUPCC, Article 8 (1)).

Unlike the IACAC, both the UNCAC and AUCPCC leave it up to the states parties to adopt legislation criminalizing illicit enrichment. As a consequence, some states parties with a long and sordid history of highlevel official corruption have elected not to criminalize the crime of illicit enrichment (Lindy Muzila et al, 2012, p.9).

\subsection{Essential Elements of Illicit Enrichment Crime}

To properly identify the basic elements of the crime of illicit enrichment, one has to refer to the law that criminalizes such form of behavior and should focus on the law that defines the crime (Worku Yaze Wadago, 2014, p.56).The elements of an offence are the bases of criminal investigation, prosecution and conviction. It is the identification and subsequent establishment of the essential elements of an offence that enable courts of law to convict and punish persons accused of committing some form of crime (Worku Yaze Wadago, 2014, p.56).

As Muzila et al has rightly noted, illicit enrichment crime has contained five basic ingredient elements(Lindy Muzila et al, 2012, p.13): (i) Targeting Public Officials; (ii) Period of Check; (iii) Identifying Significant Increase in Assets; (iv)Mental Element; and (v) Absence of Explanation. These common elements are found in almost all the definitions of the crime in the UNCAC, AUCPCC, and IACAC.

In general, one has to give special attention to these elements as are provided under the international anticorruptions conventions and national legislations.

\section{Result and Discussion}

\subsection{Legal Framework of Illicit Enrichment Crime and its Penalties in Hong Kong, Rwanda and Ethiopia}

As discussed in section, the international anti-corruption conventions to which state parties are obliged in the implementation of their international obligations in fighting corruption. Either the state may include them in their national legislation or establish appropriate special mechanisms to ensure the implementation of the anticorruption convention. Accordingly, hereunder, we will discuss and compare the legal framework of illicit enrichment crime in national legislation of Hong Kong, Rwanda and Ethiopia.

To begin, Hong Kong has promulgated law creating the crime of illicit enrichment (POBO, Section 10).It was among the first countries to criminalize illicit enrichment through the crime of possession of inexplicable wealth (Ndiva Kofele-Kale, 2012, p.30). Accordingly, illicit enrichment crime is provided in Chapter 201, Section 10, of the Prevention of Bribery Ordinance (POBO). Accordingly, Section 10 provides that:

Any person who, being or having been a prescribed officer:

a) Maintains a standard of living above that which is commensurate with his present or past official emoluments; or

b) is in control of pecuniary resources or property disproportionate to his present or past official emoluments, shall, unless he gives a satisfactory explanation to the court as to how he was able to maintain such a standard of living or how such pecuniary resources or property came under his control, be guilty of an offence.

Where a court is satisfied in proceedings for an offence under subsection (1)(b) that, having regard to 
the closeness of his relationship to the accused and to other circumstances, there is reason to believe that any person was holding pecuniary resources or property in trust for or otherwise on behalf of the accused or acquired such resources or property as a gift from the accused, such resources or property shall, in the absence of evidence to the contrary, be presumed to have been in the control of the accused.

As it is clearly stated in this provision, the possession of unexplained property by a public officer, either by maintaining a living standard above that which is commensurate with his present or past official emoluments or by being in control of property disproportionate to his present or past official emoluments, is considered a punishable crimes, unless the public officer provides a satisfactory explanation (POBO, Section 10). The sanctions foreseen for the conviction of crimes under Section 10 are a fine up to one million dollars and a prison term of up to ten years (POBO, Section 12). And section 12AA further provides that, where a person is convicted on indictment under Section 10(1)(b), the court may also order the confiscation of the unexplained assets(POBO, Section 12AA).

Likewise, in Rwanda, crime of illicit enrichment by public officials as well as any individual has been criminalized under law related to the punishment of corruption crimes. Accordingly, Article 9 of law on fighting against corruption state that: "Any person who cannot justify the source of his or her assets compared with his or her lawful income commits an offence" (Law on Fighting Against Corruption in Rwanda). From the outset it has to be clear that the law extends the crime to any persons whether in public office or in the private sector or employment who commits the crime of illicit enrichment. With regard to the punishment attached the crime, it was provided that perpetrator will be sentenced for a term of not less than seven (7) years but not more than ten (10) years with a fine of three (3) to five (5) times the value of the property the legal source of which, he or she is not able to justify (Law on Fighting Against Corruption in Rwanda, Article 9). Further, the court of law will automatically deliver the verdict of the confiscation of the illicit property or revenue (Law on Fighting Against Corruption in Rwanda, Article 9).

Similarly, Ethiopia has been introduced possession of unexplained property as one form of corruption crime under Article 419 of the FDRE Criminal Code since 2004 (Proclamation No.414/2004, Negarit Gazeta, No., Year, $9^{\text {th }}$ of May, 2005). Later, it was amended by Corruption Crimes Proclamation in 2015(Proclamation, No. 881/2015,Negarit Gazeta, $21^{\text {st }}$ Year No.36, Addis Ababa, $3^{\text {rd }}$ April, 2015). Accordingly, Article 21 of Corruption Crimes Proclamation which is titled as "Possession of Unexplained Property" elaborated what constituted it and punishment attached to such crime. Accordingly, Article 21 of the Corruption Crimes Proclamation, No. $881 / 2015$ provides that:

1) Any public servant or employee of a public organization, being or had been in office, who:

a) Maintains a standard of living above that which is commensurate with the official income from his present or past occupation or other means; or

b) Is in control of pecuniary resources or property disproportionate to the official income from his present or past occupation or other means;

Unless he proves satisfactorily before the court of law as to how he was able to maintain such a standard of living or how such pecuniary resources or property came under his control, shall be punishable, without prejudice to the confiscation of the property or the restitution to the third party, with simple imprisonment and fine, or in serious cases, with rigorous imprisonment not exceeding five years and fine not exceeding Birr five thousand.

Where the court, during proceeding under paragraph (b) sub-article (1) of this Article is satisfied that there is reason to believe that any person, owing to his closeness to the accused or other circumstances, was holding pecuniary resource or property in trust for or otherwise on behalf of the accused, such resource, or property shall, in the absence of evidence to the contrary, be presumed to have been under the control of the accused.

According to this provision, it is a crime for any present or past public servant or employee of a public organization to maintain or have maintained a standard of living above that which is commensurate with his present or previous official income from his present or past employment or other legitimate source unless such person gives a satisfactory explanation thereof. It is a crime for a public servant or employee of a public organization to be in control of pecuniary resources or property disproportionate to his official income from his present or past employment or other legitimate source of income unless such person gives a satisfactory explanation thereto. It is also important to note that illicit enrichment provision extend the crime to the public official's relatives or associates who may be in possession or ownership of the illegal income and asset. Accordingly, it is also a crime if such a person is found possessing such a disproportionate amount of money or other property through another person such as close relatives, or associates. In relation to penalty imposed up on perpetrators of illicit enrichment crime, without prejudice to the confiscation of the property or the restitution to the third party, the provision of the corruption crimes proclamation prescribes a maximum of five years' imprisonment and a fine not exceeding Birr five thousand. 


\subsection{Comparison of Penalty Attached to Illicit Enrichment Crime in Ethiopia, Hong Kong and Rwanda}

The FDRE Criminal Code embarks punishment as one of the mechanisms to achieve the purpose of criminal law to preserve the peace and security of society along with giving due notice and measures (The FDRE Criminal Code, Article 1; FDRE Criminal Code, 2007, Explanatory note ,p.2; Dejene Girma, 2012, p. 5). Punishment, among other things, aims at achieving the goals of deterrence and rehabilitation (Dejene Girma, 2012, p.5). The Code adopts the determinate sentencing statute which is a model of criminal punishment in which an offender is given a fixed term that may be reduced by good time or earned time (Dejene Girma and Mekonnen Feleke, 2009, Pp.31-33; Lawrence, A and Lyons,D, 2011, p.31). Currently, the Federal Supreme Court issued Sentencing guideline with the view to reduce sentencing disparity, ensure uniformity and correctness of sentencing among offenders of the crime (The FDRE Criminal Code, Article 88(4); Federal Supreme Court Amended Sentencing Guideline, 2014, Article 3). Thus, the legislature in fixing the range of punishment, the judiciary in fixing exact penalty and executive organs in executing imposed penalty should not exercise their power arbitrarily(Dejene Girma and Mekonnen Feleke, 2009, Pp.31-33; Lawrence, A and Lyons,D, 2011, p.31). Rather, they are required to consider the principles and policies of sentencing. These include principle of legality, equality, consistency, proportionality, predictability, and respect for human dignity, accountability, and transparency (Federal Judicial Professionals Training Center: Manual on Sentencing Guideline, 2011, p.5).

As stated above, Article 21 of the Corruption Crimes Proclamation No. 881/2015 of Ethiopia prescribe a maximum of five years' imprisonment and a fine not exceeding Birr five thousand for crime of illicit enrichment Hereunder, the law doesn't specify the minimum year's imprisonment and minimum amount of fine. Further, the rationality and appropriateness of the penalty provided for illicit enrichment crime is also questionable.

For instance, in the case of Prosecutor v. Elizabeth Welde Gebriel et al(The Federal High Court, File Number 62293), judgment given on 8 July, (2011), p.24), the Federal High Court found Mulugeta Yayeh Zewdei guilty of the illicit enrichment crime. The accused was an employee of a metal factory, a public enterprise, with a monthly salary of 3,778 Ethiopian Birr (ETB). The charge against him shows that the accused owned four houses and two plots of land in Finfinne (Addis Ababa), the capital of Ethiopia. He also had 158, 964.8 ETB in his personal banking account. The Federal High Court after found him guilty of illicit enrichment crime within the meaning of Article 419(1)(a) and (b) of the Criminal Code and sentenced him to three years' imprisonment and a 7,000 ETB fine.

In another case of Oromia Ethics and Anti-Corruption Commission (OEACC) Prosecutor v. Zelalem Jemane et al (Oromia Special Zone Surrounding Finfinne High Court, Judgment, Criminal File No.14761, $(28 / 03 / 2010$ E.C) $)$, the OEACC Prosecutor filed amended charges ( $1^{\text {st }}$ count $)$ against $1^{\text {st }}, 2^{\text {nd }}$ and $3^{\text {rd }}$ defendants before Oromia Special Zone Surrounding Finfinne High Court based on Article 32(1) (a) of Criminal Code and Article 21(1)(a)(b) of Corruption Crime Proclamation No. 881/2007 on 29 February, 2009 E.C (Ethiopian Calendars). The specific charge against them shows that while they were lived as husband and wife, and served as a public servant in various public offices between 1984 E. C and 2008 E. C, the defendants were owned unregistered assets as contrary to Asset Disclosure and Registration Proclamation (No.668/2010, Negarit Gazeta, $16^{\text {th }}$ Year No. 18, Addis Ababa 12 ${ }^{\text {th }}$ April, 2010) and disproportionate to their present and past employment and other legitimate income estimated totally amount to $31,769,302.00 \mathrm{ETB}$. The court after examining both side evidences has pronounced verdict on the defendants on 28 December, 2010 E.C, and found them guilty of possession of unexplained property, and also sentenced each of them to one years' rigorous imprisonment and a 1,000 ETB fine.

In the context of criminal law, the punishment should consider the degree of individual guilty, dangerous disposition of criminal, antecedents, motive and purpose, his personal situation as well as the gravity of the crime and the circumstances of its commission(FDRE Criminal Code, Article 88(2); Hough, M et al, 2009, p.23). In the above two cases, it is worthy to surmise that the law fails to set minimum limit of penalty and entails severe punishment in terms of imprisonment and fine that can convey a meaningful message to potential offenders. This problem intern gave a chance for a judge to exercise his or her power arbitrarily while imposing penalty attached to illicit enrichment crime. In this respect, a judge should be more aware of the clandestine and the sophisticated nature of the commission of illicit enrichment crime as well as required to consider the principles and policies of sentencing.

To compare and contrast the penalty attached to illicit enrichment crime in the Ethiopia, Hong Kong and Rwanda, the author has considered their respective legal regimes that can been seen in Table 1 as follows. 
Table 1: Comparison of penalties attached to Illicit Enrichment crime in Ethiopia, Hong Kong and Rwanda.

\begin{tabular}{|c|c|c|c|}
\hline \multirow[t]{2}{*}{ Country } & \multirow{2}{*}{$\begin{array}{l}\text { Date of } \\
\text { Legislation }\end{array}$} & \multicolumn{2}{|c|}{ Penalty for Infringement } \\
\hline & & $\begin{array}{l}\text { Prison } \\
\text { Sentence }\end{array}$ & Fine and/or Confiscation of gains \\
\hline $\begin{array}{l}\text { Hong } \\
\text { Kong }\end{array}$ & 1971 & $3-10$ years & $\begin{array}{ll}\checkmark & 100 \mathrm{k}-1 \mathrm{~m} \mathrm{HK} \$ ; \\
\checkmark & \text { Confiscation of the } \\
& \text { unexplained assets }\end{array}$ \\
\hline Rwanda & 2003 & $2-5$ years & $\begin{array}{ll}\checkmark & 2 \text {-10-times value of gains ; } \\
\checkmark & \text { Confiscation of the illicit property or revenue }\end{array}$ \\
\hline Ethiopia & 2015 & Up to 5 years & $\begin{array}{l}\checkmark \quad \text { Not exceeding } 5,000 \text { Ethiopian Birr; } \\
\checkmark \quad \text { Confiscation of the property or the restitution to the } \\
\text { third party }\end{array}$ \\
\hline
\end{tabular}

In comparison to the experiences of Hong Kong and Rwanda, in terms of imprisonment and fine imposed on perpetrator, Ethiopia's Corruption Crime Proclamation regulating illicit enrichment crime is inadequate to deter corrupt practices. Under anti-corruption laws of both the Hong Kong and Rwanda, the crime of illicit enrichment receives severe punishment which has a deterrent effect. Furthermore, unlike Rwanda, Ethiopian Corruption Crime Proclamation fails to set a minimum penalty provided for illicit enrichment crime. Thus, in absence of limiting a minimum penalty being provided for such offences, courts have the discretion to decide. In this scenario, where the discretion is abused, the perpetrators may receive a punishment which is light in proportion to the gravity of the offence. In such a case, the purpose and goal of criminal law to ensure order, peace, and security of the state and its inhabitants for public good became endangered as the system encourages dangerous disposition of the criminal. In effect, the law fails to achieve the deterrence rationales of sentencing. Moreover, the act makes justice system to lose public confidence and leads to disobedience of the laws. Ironically, the law should have set minimum limit of penalty and entails severe punishment in terms of imprisonment and fine that can convey a meaningful message to potential offenders. Therefore, Ethiopia needs to draw a lesson from the experiences of the Hong Kong and Rwanda in incorporating severe and setting minimum limit of penalty for crime of illicit enrichment.

\section{Concluding Remarks}

With the view to eradicating corruption crimes, the Corruption Crimes Proclamation No.881/2015 criminalizes illicit enrichment crime under Article 21. However, the penalty of provision entitles the wrongdoer to benefit from his own wrong by making the punishment of illicit enrichment crime less severe. Moreover, the law fails to set a minimum limit of penalty and fine entitles to illicit enrichment crime, and thus allows the courts to release the offender only upon his or her discretion. Designing the law in such manner daunt the purpose and goal of criminal law to ensure order, peace, and security of the state and its inhabitants for the public good and jeopardize the public interest at large. Thus, Ethiopia needs to draw a lesson from the experiences of the Hong Kong and Rwanda in incorporating severe and setting minimum limit of penalty for crime of illicit enrichment that can convey a meaningful message to potential offenders. Therefore, the law makers should repeal the existing penalty of illicit enrichment crime and replace with the fitting penalty.

\section{References}

\section{Legal Instruments}

African Union Convention on Preventing and Combating Corruption adopted on 11 July 2003 at the African Union Summit in Maputo, Mozambique and entered into force on 5 August 2005.

Inter-American Convention against Corruption adopted on 29 March 1996 at Caracas, Venezuela and entered in to force on 3 June 1997 under the framework of Organization of American States.

United Nations Convention against Corruption adopted by General Assembly Resolution G.A.Res. 58/4, U.N. Doc. A/RES/58/4 of 31 October 2003 and entered in to force 9 December 2005.

Assets Disclosure and Registration Proclamation No.668/2010, Negarit Gazeta, $16^{\text {th }}$ Year No. 18, Addis Ababa $12^{\text {th }}$ April, 2010.

Corruption Crimes Proclamation, No. 881/2015, Negarit Gazeta $22^{\text {st }}$ Year No.36, Addis Ababa, $3^{\text {rd }}$ April, 2015.

The Criminal Code of the Federal Democratic Republic of Ethiopia, Proclamation No.414/2004, Negarit Gazeta, No. , Year, $9^{\text {th }}$ of May, 2005.

Law № 54/2018 OF 13/08/2018 on Fighting Against Corruption, Official Gazette, no. Special of 20/09/2018.

Prevention of Bribery Ordinance (1971), Cap 201 Laws of Hong Kong, Section 10.

Proclamation No. 545/2007, a proclamation to provide for the ratification of the AUCPCC.

Proclamation No. 544/2007, a proclamation to provide for the ratification of the UNCAC. 
Cases

Oromia Ethics and Anti-Corruption Commission (OEACC) Prosecutorv. Zelalem Jemane et al, Oromia Special Zone Surrounding Finfinne High Court, Judgment, Criminal File No.14761, (28/03/2010 E.C).

Prosecutor v. Elizabeth Welde Gebriel et al,(The Federal High Court, File Number 62293), judgment given on 8 July, (2011), 24.

\section{Books}

Dejene Girma. (2012). A Handbook on the Criminal Code of Ethiopia, Printed by Far East P.L.C.

Lindy Muzila et al.(2012). On the Take: Criminalizing Illicit Enrichment to Fight Corruption, Washington, DC: World Bank.

Ndiva Kofele-Kale. (2012). Combating Economic Crimes: Balancing Competing Rights and Interests in Prosecuting the Crime of Illicit Enrichment, Oxford: UK, First Published by Routledge Research in Transnational Crime and Criminal Law.

\section{Journal Articles}

Jeffrey R. Boles. (2014). Criminalizing the Problem of Unexplained Wealth: Illicit Enrichment Offenses and Human Rights Violation, New York University, Journal of Legislation and Public Policy, 17, No. 4.

Mohannad Ahmad et al. (2016). The Law on the Illicit Enrichment Crime and Financial Disclosure in Jordan: Issue of Effectiveness and Enforceability, The Journal of Social Sciences Research, Vol. 2, No. 5.

Mouhamed Bachir. (2017).National Mechanisms Against Illicit Enrichment Case Study: Senegal, Journal of Justice, Vol, 1(1).

Okechukwu, Igwe \& Ezenwafor. (2017).African Anti-Corruption Agencies: Challenges and Prospects, Management Studies and Economic Systems (MSES), 3(4) Spring, Pp. 225-243.

WorkuYaze Wadago.(2014). Criminalization of Possession of Unexplained Property and the Fight Against Public Corruption: Identifying the Elements of the Offence under the Criminal Code of Ethiopia, Mizan Law Review, Vol. 8, No.1, Pp.45-83.

\section{Working Paper, Report and Guidelines}

Birney, M. (2013). The London School of Economics and Political Science, Decentralization and Veiled Corruption under China's Rule of Mandates.

Dejene Girma and Mekonnen Feleke.(2009). Sentencing and Execution Teaching Material, Sponsored by the Federal Justice and Legal System Research Institute.

FDRE Criminal Code. (2007): Explanatory note.

Federal Judicial Professionals Training Center. (2011). Manual on Sentencing Guideline.

Federal Supreme Court Amended Sentencing Guideline (2014).

Hough, M et al. (2009). Public attitudes to Principles of Sentencing, Sentencing Advisory Panel Research Report.

Lawrence, A and Lyons, D.(2011). Principles of Effective State Sentencing and Corrections Policy”, A Report of the National Conference of State Legislatures, Sentences and Corrections Work Group, Augest 2011.

Max Weylandt. (2017). The Crime of illicit enrichment in Namibia: New Opportunities for enforcement? Briefing Paper.

\section{Internet Sources}

Corruption Perception Index 2017. Retrieved from www.transparency.org/cpi .

Corruption Perception Index 2018. Retrieved from www.transparency.org/cpi .

Corruption Perception Index 2019. Retrieved from www.transparency.org/cpi .

Karen Zadoyan.(2014). International Experience of the Criminalization of Illicit Enrichment, and the Possibilities of criminalizing Illicit Enrichment in Armenia. Retrieved from https://iravaban.net/wpcontent/uploads/2014/12/Illicit-enrichment-Eng.pdf

UNODOC, Signatories to the UNCAC, 2 April, 2019. Retrieved from https://www.unodc.org/unodc/en/corruption/ratification-status.html. 